\title{
Model Pertumbuhan Utang Luar Negeri Indonesia
}

\author{
Kharida Aulia Bahri $^{\# 1}$, Muhammad Subhan ${ }^{* 2}$, Riry Sriningsih ${ }^{* 3}$

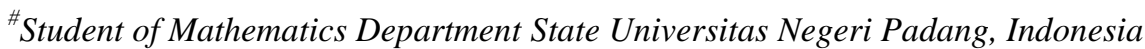 \\ *Lecturers of Mathematics Department State Universitas Negeri Padang, Indonesia \\ ${ }^{1}$ kharidaabegmail.com \\ ${ }^{2} 13$ subhanegmail.com \\ ${ }^{3}$ srirysriningsiheyahoo. com
}

\begin{abstract}
The Government of Indonesia do external debt because government expenditure is greater than his revenue. External debt of Indonesia increas every year. To see its growth, it can be done with make a model of Indonesia's external debt. This research is literature study. The model of the growth of Indonesia's external debt in form of linear differential equations of first order that the solution can be determined. From the analysis results, Indonesia's external debt affected by the interest rate, the expenditure rate, the tax revenue rate and non-tax revenue rate.
\end{abstract}

Keywords - mathematical model, tax, non-tax revenue, expenditure, external debt

Abstrak - Pemerintah Indonesia melakukan utang luar negeri karena pengeluaran pemerintah lebih besar dari pendapatannya. Utang luar negeri Indonesia ini terus meningkat dari tahun ke tahun. Untuk pertumbuhannya, dapat dilakukan dengan memodelkan utang luar negeri Indonesia. Penelitian ini merupakan studi kepustakaan. Model pertumbuhan utang luar negeri Indonesia berbentuk persamaan diferensial linier orde satu yang solusinya dapat ditentukan. Dari hasil analisis terhadap model, utang luar negeri Indonesia dipengaruhi oleh tingkat bunga utang luar negeri, tingkat pengeluaran, tingkat pendapatan pajak dan tingkat pendapatan bukan pajak.

Kata kunci - model matematika, pajak, pendapatan bukan pajak, pengeluaran, utang luar negeri

\section{PENDAHULUAN}

Utang luar negeri merupakan pinjaman dana kepada pihak asing, baik suatu negara maupun badan-badan internasional dengan kewajiban membayar kembali beserta bunganya. Indonesia merupakan salah satu negara yang memiliki utang luar negeri. Pemerintah Indonesia melakukan utang luar negeri karena pengeluaran pemerintah lebih besar dari pendapatannya, baik pendapatan pajak maupun pendapatan bukan pajak. Sehingga utang dijadikan sebagai alat untuk menutupi defisit anggaran pemerintah.

Selama ini pemerintah menganggap bahwa utang merupakan bagian dari proses pembangunan ekonomi. Tapi pada kenyataannya, porsi ketergantungan anggaran terhadap utang semakin meningkat dan terus menjerat APBN dari tahun ke tahun [5]. Akibatnya jumlah utang luar negeri Indonesia juga semakin meningkat.
Beban utang luar negeri Indonesia dapat dilihat dari total utang dan rasio utang terhadap Produk Domestik Bruto (PDB). PDB merupakan penghasilan keseluruhan dari suatu negara. Semakin kecil rasio utang terhadap PDB, maka semakin bagus untuk suatu negara. Hal ini menunjukkan bahwa pendapatan negara yang besar dan utang yang kecil. Jika rasio utang luar negeri terhadap PDB semakin besar, maka harus diwaspadai. Rasio utang luar negeri pemerintah Indonesia terhadap PDB maksimal $60 \%$ [4].

Pada awal orde baru, tahun 1969, utang luar negeri Indonesia berjumlah USD 2,437 miliar. Pada awal reformasi, utang luar negeri Indonesia terhitung USD 150,886 miliar, dan pada tahun 2015, utang luar negeri Indonesia berjumlah USD 304,388 miliar, dengan rasio utang luar negeri Indonesia terhadap PDB adalah $34,43 \%$. Jumlah utang luar negeri Indonesia dapat dilihat pada gambar 1 . 


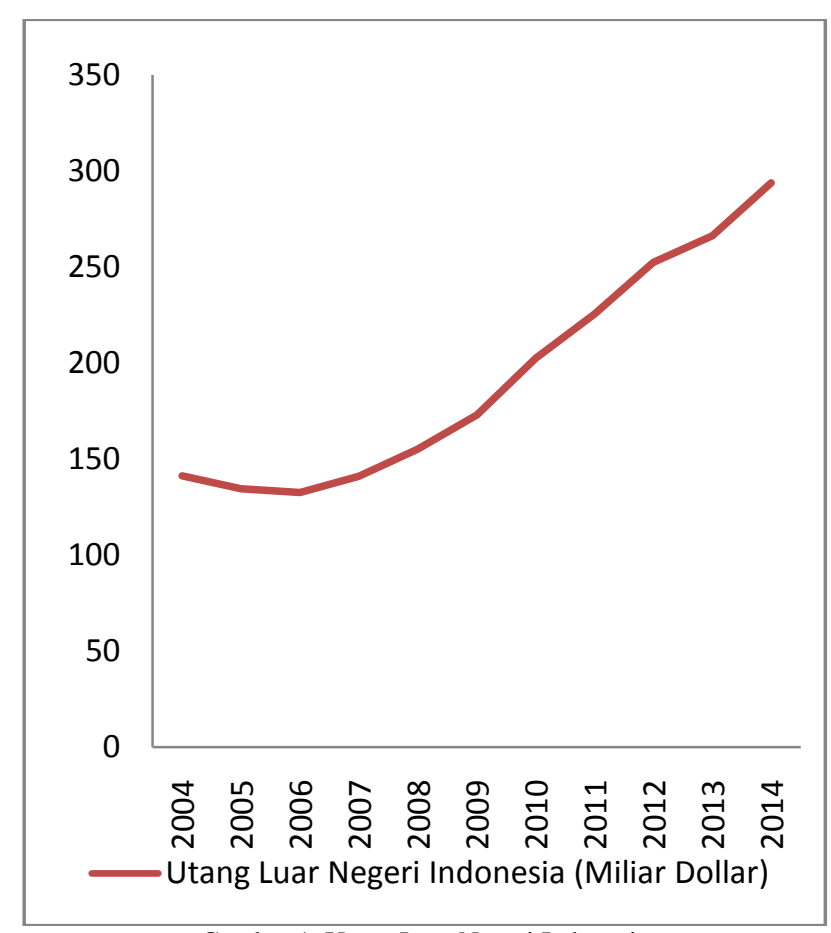

Gambar 1. Utang Luar Negeri Indonesia

Peningkatan jumlah utang luar negeri ini berimplikasi terhadap jumlah pembayarannya, yaitu cicilan pokok dan bunganya. Jumlah cicilan utang luar negeri pemerintah Indonesia dapat dilihat pada tabel I.

TABEL I

CiCIClAN UTANG LUAR NEGERI INDONESIA

\begin{tabular}{|c|c|c|c|}
\hline \multirow{2}{*}{ Tahun } & \multicolumn{3}{|c|}{ Pembayaran (Miliar USD) } \\
\cline { 2 - 4 } & Pokok & Bunga & Total \\
\hline 2004 & 6,226 & 2,843 & 9,069 \\
\hline 2005 & 7,024 & 2,779 & 9,803 \\
\hline 2006 & 14,130 & 2,949 & 17,079 \\
\hline 2007 & 6,367 & 3,640 & 10,007 \\
\hline 2008 & 6,405 & 2,810 & 9,215 \\
\hline 2009 & 6,742 & 2,768 & 9,510 \\
\hline 2010 & 5,404 & 2,743 & 8,147 \\
\hline 2011 & 3,482 & 2,315 & 5,796 \\
\hline 2012 & 3,387 & 2,343 & 5,730 \\
\hline 2013 & 5,467 & 2,867 & 8,334 \\
\hline 2014 & 8,011 & 2,912 & 10,923 \\
\hline
\end{tabular}

Jika terus dibiarkan, beban utang ini dapat menggrogoti keuangan negara, karena anggaran negara (APBN) tersedot untuk membayar cicilan dan bunga utang. Dampaknya adalah negara dipaksa mengefisienkan pengeluaran untuk sektor-sektor yang lebih strategis, seperti sektor pembangunan infrastruktur, pendidikan, kesehatan, dan lain-lain [8]. Dalam jangka panjang, utang luar negeri pemerintah tersebut dapat menyebabkan berkurangnya kemakmuran dan kesejahteraan rakyat pada masa mendatang, sehingga akan membebani masyarakat, khususnya para wajib pajak di Indonesia [1].

Untuk itu, diperlukan penanganan utang luar negeri dari pemerintah. Hal yang mungkin dilakukan adalah pemanfaatan dan peruntukan anggaran yang telah diperoleh dari pinjaman luar negeri harus dapat terealisasi dengan baik, tepat sasaran dan memenuhi kaidah akuntabilitas dengan mempertimbangkan skala prioritas pembangunan nasional serta terbebas dari berbagai masalah penyimpangan atau penyelewengan [7]. Selain itu, dapat dilakukan pengurangan utang luar negeri secara bertahap, dan mencari sumber penerimaan di dalam negeri, yaitu penerimaan pajak dan penerimaan negara bukan pajak.

Secara umum, faktor-faktor penyebab pertumbuhan utang luar negeri Indonesia masih bisa diketahui. Dengan mengetahui keterkaitan antar faktor tersebut diharapkan dapat mempermudah dalam memahami laju pertumbuhannya. Keterkaitan antar faktor dapat diketahui dengan menggunakan model matematika. Model ini memperhatikan pengeluaran dan pendapatan pemerintah, dimana pendapatan pemerintah terdiri atas pendapatan pajak dan pendapatan bukan pajak. Setelah model terbentuk, dilakukan analisis terhadap model dengan mencari solusinya. Dari hasil analisis, diinterpretasikan model pertumbuhan utang luar negeri Indonesia.

Model pertumbuhan utang luar negeri Indonesia ini menggunakan persamaan diferensial, yaitu persamaan diferensial peubah terpisah dan persamaan diferensial linier orde satu.

\section{Metode}

Penelitian ini adalah penelitian dasar. Adapun metode yang digunakan adalah studi kepustakaan dengan menganalisis teori-teori yang relevan terhadap permasalahan yang dibahas. Langkah-langkah untuk mendapatkan jawaban dari permasalahan yaitu:

1. Menentukan masalah yang akan dibahas dari model pertumbuhan utang luar negeri Indonesia.

2. Membuat asumsi-asumsi yang dapat membantu dalam membentuk model.

3. Membentuk model pertumbuhan utang luar negeri Indonesia.

4. Menentukan solusi dari persamaan model pertumbuhan utang luar negeri Indonesia.

5. Menginterpretasikan model pertumbuhan utang luar negeri Indonesia.

\section{HASIL DAN PEMBAHASAN}

\section{A. Formulasi Model}

Dalam pembentukan model pertumbuhan utang luar negeri Indonesia digunakan variabel, yaitu

- $I(t)$ adalah pendapatan pemerintah (USD)

- $T(t)$ adalah pendapatan pajak (USD)

- $N(t)$ adalah pendapatan bukan pajak (USD)

- $E(t)$ adalah pengeluaran pemerintah (USD)

- $D(t)$ adalah utang luar negeri (USD) 
dengan satuan waktunya per tahun. Sedangkan parameter yang digunakan yaitu

- $\alpha$ adalah tingkat pendapatan pajak (persen per tahun)

- $\quad \beta$ adalah tingkat pendapatan bukan pajak (persen per tahun)

- $\quad \gamma$ adalah tingkat pengeluaran pemerintah (persen per tahun)

- $\lambda$ adalah tingkat bunga utang luar negeri (persen per tahun)

Pembentukan model ini menggunakan asumsi sebagai berikut

1. Tingkat bunga utang luar negeri konstan

2. Tingkat pendapatan pajak konstan

3. Tingkat pendapatan bukan pajak konstan

4. Tingkat pengeluaran konstan

Dari variabel, parameter dan asumsi tersebut, dibentuk model pertumbuhan utang luar negeri Indonesia. Laju pertumbuhan utang luar negeri Indonesia dipengaruhi oleh besarnya bunga utang luar negeri dan defisit anggaran, yaitu pengeluaran pemerintah lebih besar dari pendapatan pemerintah. Sedangkan pendapatan pemerintah terdiri atas pendapatan pajak dan pendapatan bukan pajak. Sehingga diperoleh persamaan

$$
\frac{d D}{d t}=\lambda D+E-I
$$

dengan

$$
I=T+N
$$

dimana

$$
\begin{aligned}
& \frac{d T}{d t}=\alpha T \\
& \frac{d N}{d t}=\beta \mathrm{N} \\
& \frac{d E}{d t}=\gamma E
\end{aligned}
$$

\section{B. Analisis Model Pertumbuhan Utang Luar Negeri Indonesia}

Model pertumbuhan utang luar negeri Indonesia di analisis dengan mencari solusi dari persamaan tersebut.

\section{Pendapatan Pemerintah Indonesia}

Pendapatan pemerintah Indonesia terdiri atas pendapatan pajak dan pendapatan bukan pajak. Untuk itu, terlebih dahulu dicari solusi dari persamaan pendapatan pajak dan persamaan pendapatan bukan pajak.

Persamaan pendapatan pajak merupakan persamaan diferensial peubah terpisah [3], sehingga dapat ditulis

$$
\frac{d T}{T}=\alpha d t
$$

Dengan mengintegralkannya, diperoleh

$$
T(t)=T(0) e^{\alpha t}
$$

Sedangkan persamaan pendapatan bukan pajak merupakan persamaan diferensial peubah terpisah [3], sehingga dapat ditulis

$$
\frac{d N}{N}=\beta d t
$$

Dengan mengintegralkannya, diperoleh solusi

$$
N(t)=N(0) e^{\beta t}
$$

Dengan mensubstitusikan persamaan (6) dan (7) ke persamaan (2), diperoleh solusi dari persamaan pendapatan pemerintah yaitu

$$
I=T(0) e^{\alpha t}+N(0) e^{\beta t}
$$

2. Pengeluaran Pemerintah Indonesia

Persamaan pengeluaran pemerintah merupakan persamaan diferensial peubah terpisah [3], sehingga dapat ditulis

$$
\frac{d E}{E}=\gamma d t
$$

Dengan mengintegralkannya, diperoleh solusi

$$
E(t)=E(0) e^{\gamma t}
$$

3. Utang Luar Negeri Indonesia

Model pertumbuhan utang luar negeri Indonesia merupakan persamaan diferensial linier orde satu [6]. Solusinya dapat dicari dengan mengalikan persamaan diferensial dengan faktor integrasinya.

Faktor integrasi dari persamaan utang luar negeri adalah

$$
e^{(-\lambda t)}
$$

Dengan mengalikan persamaan utang luar negeri dengan faktor integrasinya, diperoleh solusi

$$
D=e^{\lambda t} \int e^{(-\lambda t)}(E-I) d t
$$

Karena E dan I sudah diperoleh, maka substitusikan E dan I ke persamaan (10), diperoleh

$D=e^{\lambda t} \int e^{-\lambda t}\left(E(0) e^{\beta t}-\left(I_{T}(0) e^{\alpha_{1} t}+I_{N}(0) e^{\alpha_{2} t}\right)\right) d t$

Sehingga diperoleh solusi dari persamaan utang luar negeri Indonesia yaitu 


$$
D=\frac{E(0) e^{\gamma t}}{\gamma-\lambda}-\frac{T(0) e^{\alpha t}}{\alpha-\lambda}-\frac{N(0) e^{\beta t}}{\beta-\lambda}
$$

\section{Simulasi Model Pertumbuhan Utang Luar Negeri Indonesia}

Simulasi dari solusi model pertumbuhan utang luar negeri Indonesia dilakukan dengan membentuk kurva dari beberapa nilai parameter yang berbeda, yaitu

1. $E(0)=155,1, T(0)=107,8, N(0)=32,6$

$\gamma=0,04, \alpha=0,05, \beta=0,01, \lambda=0,06$

$D(0)=293,7$

$$
D=\frac{151,1 e^{0,04 t}}{0,04-0,06}-\frac{107,8 e^{0,05 t}}{0,05-0,06}-\frac{32,6 e^{0,01 t}}{0,01-0,06}
$$

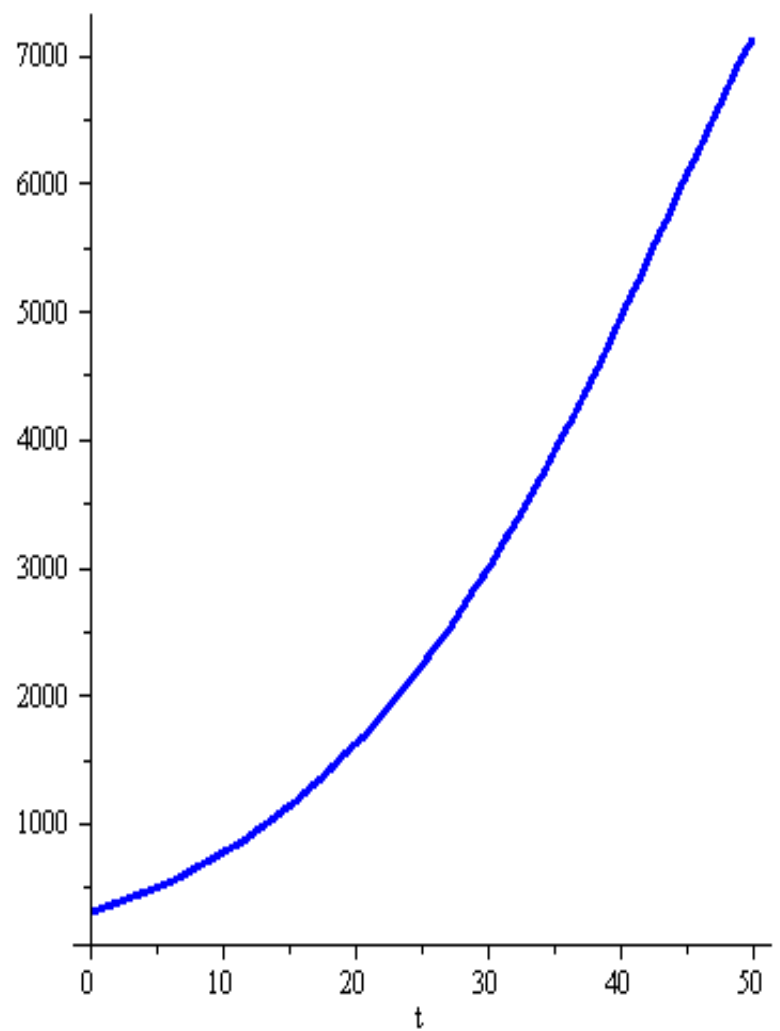

Gambar 2. Kurva Utang Luar Negeri Indonesia dengan Tingkat Bunga Utang Luar Negeri Tinggi

Dari kurva dapat dilihat bahwa semakin bertambahnya waktu, utang luar negeri Indonesia semakin bertambah dengan tingkat bunga 0,06 .

2. $E(0)=155,1, T(0)=107,8, N(0)=32,6$

$\gamma=0,04, \alpha=0,05, \beta=0,01, \lambda=0,02$

$D(0)=293,7$

$D=\frac{151,1 e^{0,04 t}}{0,04-0,02}-\frac{107,8 e^{0,05 t}}{0,05-0,02}-\frac{32,6 e^{0,01 t}}{0,01-0,02}$

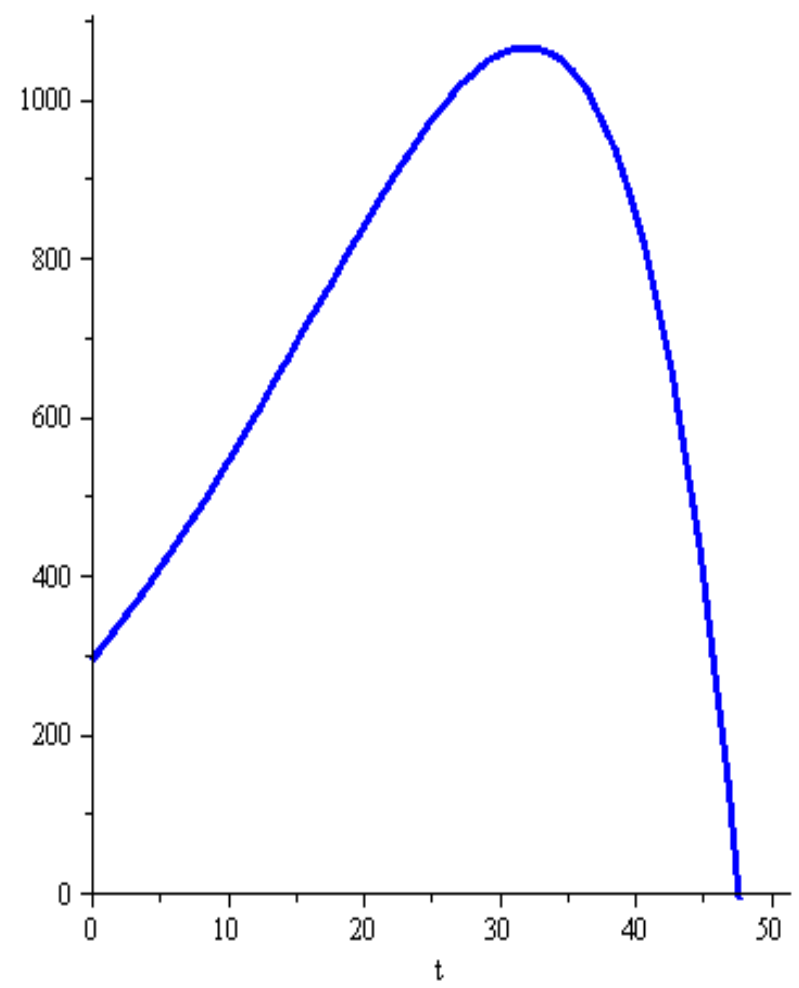

Gambar 3. Kurva Utang Luar Negeri Indonesia dengan Tingkat Bunga Utang Luar Negeri Rendah

Dari kurva dapat dilihat bahwa dengan tingkat bunga 0,02 , utang luar negeri Indonesia bertambah hingga tahun ke-32, dan selanjutnya berkurang hingga tahun ke- 47 .

\section{Interpretasi Model Pertumbuhan Utang Luar Negeri Indonesia}

Berdasarkan hasil analisis model, persamaan (11) menyatakan besarnya jumlah utang luar negeri Indonesia. Dari simulasi terhadap solusi model diperoleh bahwa utang luar negeri Indonesia akan berkurang jika tingkat pengeluaran turun dan tingkat pendapatan pajak dan bukan pajak naik, dengan syarat tingkat pengeluaran lebih kecil dari tingkat bunga utang luar negeri dan tingkat pendapatan pajak dan bukan pajak lebih besar dari tingkat bunga utang luar negeri.

Jika tingkat bunga utang luar negeri naik, maka pemerintah harus menurunkan tingkat pengeluaran pemerintah, dan menaikkan tingkat pendapatan pajak dan tingkat pendapatan bukan pajak. Jika tingkat bunga utang luar negeri turun, maka pemerintah harus menurunkan tingkat pengeluaran pemerintah, sedangkan tingkat pendapatan pajak dan tingkat pendapatan bukan pajak tetap.

\section{SIMPULAN}

Dari pembahasan yang telah dilakukan, dapat disimpulkan bahwa model pertumbuhan utang luar negeri Indonesia berbentuk persamaan diferensial linear orde 
satu yang dapat ditentukan solusinya. Dari solusi, diperoleh bahwa utang luar negeri Indonesia akan berkurang jika tingkat pengeluaran turun dan tingkat pendapatan pajak dan bukan pajak naik, dengan syarat tingkat pengeluaran lebih kecil dari tingkat bunga utang luar negeri dan tingkat pendapatan pajak dan bukan pajak lebih besar dari tingkat bunga utang luar negeri.

Jika tingkat bunga utang luar negeri naik, maka pemerintah harus menurunkan tingkat pengeluaran pemerintah, dan menaikkan tingkat pendapatan pajak dan tingkat pendapatan bukan pajak. Jika tingkat bunga utang luar negeri turun, maka pemerintah harus menurunkan tingkat pengeluaran pemerintah, sedangkan tingkat pendapatan pajak dan tingkat pendapatan bukan pajak tetap.

\section{REFERENSI}

[1] Admatja, Adwin Surya. 2008. Utang Luar Negeri Pemerintah Indonesia: Perkembangan dan Dampaknya. Universitas Kristen Petra.

[2] Bahri, Kharida Aulia. 2016. Model Pertumbuhan Utang Luar Negeri Indonesia. Universitas Negeri Padang

[3] Dass, H. K. 1997. Mathematics For Engineers. New Delhi: Rajendra Ravindra Printers.

[4] Kementrian Keuangan Republik Indonesia. Utang Indonesia Terus Dapat Dijaga pada Level yang Aman Januari 2014.

[5] Rachbini, Didik J. 2001. Ekonomi Politik Utang. Jakarta: Ghalia Indonesia.

[6] Ross, S. 1989. Introduction to Ordinary Differential Equation. New York : John Willey \& Sons.

[7] Saleh, Samsubar. 2008. Faktor-faktor yang Mempengaruhi Pinjaman Luar Negeri serta Imbasnya terhadap APBN. Universitas Gajah Mada.

[8] Yudiatmaja, Wayu Eko. 2012. Jebakan Utang Luar Negeri Bagi Beban Perekonomian Dan Pembangunan Indonesia. Universitas Andalas 